\title{
MUSEUS, COLECCIONISMO E VIAGENS CIENTÍFICAS EM PORTUGAL DE FINAIS DE SETECENTOS
}

\author{
Ângela Domingues \\ Centro de História da Facultade de Letras da Universidade de Lisboa \\ Email: adomingues@netcabo.pt \\ ORCID iD: http://orcid.org/0000-0002-9533-2504
}

Recibido: 8 enero 2019; Aceptado: 23 abril 2019

Como citar este artículo/Citation: Domingues, Ângela (2019), "Museus, coleccionismo e viagens cientificas em Portugal de finais de Setecentos", Asclepio, 71(2): p271. https://doi.org/10.3989/asclepio.2019.12.

RESUMO: Este artigo centra-se no vasto e complexo processo científico e institucional ligado à recolha de artefactos e à formação de colecções científico-naturais, etnológicas e antropológicas, provenientes de vários espaços coloniais extra-europeus em Portugal durante a segunda metade do século XVIII. Faz ainda referência às instituições que albergaram estes materiais. Neste período em que a ciência era, por definição, útil e devia servir ao interesse público na prossecução do bem-estar, do progresso e da felicidade dos povos, os estudos produzidos tiveram como objectivo contribuir para um levantamento científico com pretensões enciclopedistas, destinado a produzir um conhecimento minucioso dos espaços imperiais através da identificação, recolecção e estudo das produções naturais e das "características físicas e morais" dos indígenas. A curiosidade científica que caracterizou os grupos sociais envolvidos neste processo permitiu a corporização dum conjunto de práticas que era pensado em Lisboa e implementado pelos vassalos da coroa em todo o império. Deste conjunto de práticas, quero destacar as viagens filosóficas, explorações científicas vocacionadas para a descrição física e económica dos territórios e para a inventariação dos recursos naturais, consideradas como instrumento de modernização política e administrativa do império numa altura em que a ciência e a técnica eram vistas como ferramentas imprescindíveis ao desenvolvimento do Estado Moderno.

PALAVRAS CHAVE: Estado Moderno; Viagens filosóficas; Colecções; lluminismo; Museus e gabinetes de história natural.

\section{MUSEUMS, COLLECTING AND SCIENTIFIC VOYAGES IN LATE 18TH CENTURY PORTUGAL}

\begin{abstract}
This article focuses on the vast and complex scientific and institutional process related to the collection of artefacts and the formation of scientific-natural, ethnological and anthropological collections from various extra-European colonial spaces in Portugal during the second half of the eighteenth century. It also addresses the institutions that housed these materials. In a period when science was, by definition, useful and should serve the public interest in the pursuit of welfare, progress and the happiness of peoples, scientific studies had the objective of contributing to a scientific survey with encyclopaedic pretensions of the imperial spaces through the identification, collection and study of the natural productions and the "physical and moral characteristics" of the natives. The scientific curiosity that characterized the social groups involved in this process allowed the embodiment of a set of practices that was thought in Lisbon and implemented by Portuguese subjects throughout the empire. From this set of practices, I would like to highlight the philosophical voyages, scientific explorations aimed at the physical and economic description of the territories and the inventory of natural resources, considered as an instrument of political and administrative modernization of the empire at a time when science and technology were considered as essential tools for the development of the Modern State.
\end{abstract}

KEY WORDS: Modern State; Philosophical voyages; Collections; Enlightenment; Museums and Cabinets of Natural History.

Copyright: ( 2019 CSIC. This is an open-access article distributed under the terms of the Creative Commons Attribution 4.0 International (CC BY 4.0) License 
Numa altura em que, em Portugal, se discute amplamente a devolução, aos seus países de origem, do património cultural africano constituído por objectos e colecções que integram os acervos de espaços museológicos lusos - uma polémica que foi desencadeada com os pedidos de devolução dos bens culturais e patrimoniais pelos governos dos países africanos em processo de afirmação nacional (v. artigos de Lucinda Canelas e Luís Raposo no jornal Público de 07 de Dezembro de 2018) -, acredito que existe alguma pertinência em perceber melhor alguns dos processos e conjunturas que explicam a presença física de muitos destes objectos arqueológicos, etnográficos e cientifico-naturais relacionados com os antigos espaços coloniais portugueses nos nossos museus. Este é o objectivo deste artigo, que está centrado no vasto e complexo processo científico e institucional ocorrido em Portugal durante a segunda metade do século XVIII e que pretende compreender o processo de recolha de produções naturais e artefactos e entender como, neste período, se processou a constituição de colecções científico-naturais, etnológicas e antropológicas provenientes de vários espaços coloniais extra-europeus.

Alguns dos especímenes que então se recolheram persistiram até aos dias de hoje e continuam a ter um inegável significado múltiplo e polisémico. Primeiramente, porque são peças únicas e representativas do interesse setecentista pela natureza ou possuem um reconhecido valor artístico e estético, com conteúdo científico e com significado social, simbólico, mágico ou religioso, apreciadas tanto por quem as produziu como por quem as detêm e conserva. Depois, porque apesar de estes artefactos serem importantes por si próprios, se forem contextualizados e relacionados com outros - sejam eles as colecções em que estas peças se integram ou outro tipo de informação de natureza textual (descrições, memórias) ou visual (desenhos, representações em mapas) -, podem adquirir um significado bastante mais complexo e representativo dos contextos em que foram produzidos. E, last but not least, porque estes especímenes são um produto e uma representação indubitável de outros tempos, outras culturas e outros espaços; não só das africanas, americanas, asiáticas, mas também da portuguesa do lluminismo. Nesta acepção, considero que é inegável que enquanto património cultural e simbólico das sociedades indígenas, estes objectos e colecções têm ligação à memória e à pertença identitária dos povos nativos e exprimem e reflectem a pluralidade e a riqueza das identidades dos povos que os originaram. Mas este património é também um reflexo da curiosidade científica que se desenvolveu em Portugal no Século das Luzes e, consequentemente, da ciência e do coleccionismo público e privado que se produziram neste país ibérico. Este é, portanto, um património partilhado.

Torna-se agora imprescindível referir que apenas um fragmento diminuto destes artefactos recolhidos em setecentos resistiu ao desgaste do tempo e ainda subsiste actualmente. Sobreviveu a cataclismos naturais, de que o mais célebre é, sem dúvida, o Terramoto de $1755 \mathrm{ou}$, em tempos mais recentes, o incêndio do Museu Nacional de História Natural (actual MUHNAC, Universidade de Lisboa) em 1978. Escapou a episódios de guerra e de despojos de vencedores, como o que está associado à passagem do naturalista e zoólogo Étienne-Geoffroy de Saint-Hilaire pelas instituições de ciência e bibliotecas de Lisboa por altura das Guerras Peninsulares (1807-14). A sobrevivência das peças setecentistas não pode deixar de levar igualmente em consideração a história e a cultura organizacional das instituições de ciência, com as inevitáveis fundações, extinções e fusões decorrentes de renovações institucionais, de que aqui é referência apropriada o Gabinete de História Natural e Jardim Botânico da Ajuda (Fonseca, 2017, pp. 40-1). Em Portugal, continuamos a poder ver especímenes setecentistas na Colecção Maynense da Academia de Ciências de Lisboa, na Sociedade de Geografia de Lisboa, na Colecção de Antropologia do Museu da Ciência da Universidade de Coimbra, no MUHNAC, entre outras instituições.

Este artigo está centrado no Portugal das Luzes, restringindo-se esta análise especificamente ao reinado de D. Maria I. Esta é uma altura em que as instituições administrativas e científicas portuguesas estiveram particularmente activas na recolha, inventariação e organização de artefactos e especímenes naturais nos seus espaços coloniais americanos, africanos, asiáticos.

O processo é encimado pelas viagens filosóficas, explorações científicas vocacionadas para a descrição física e económica dos territórios nacional e colonial e para a inventariação dos recursos naturais e suas aplicações práticas. Estas viagens revestir-se-iam ainda de uma importância incontornável para a reorganização política e administrativa do império. Contudo, e não obstante a sua relevância, elas não são as únicas iniciativas que corroboraram neste objectivo, uma vez que ocorrem outras iniciativas que espelham o 
envolvimento dos agentes da Coroa e de particulares. Também estes indivíduos se empenharam no estudo científico dos espaços coloniais e na averiguação da utilidade e do significado económico das produções naturais, numa altura em que a ciência era, por definição, útil e devia servir ao interesse público na prossecução do bem-estar, do progresso e da felicidade dos povos.

A curiosidade científica que caracterizava esta elite permitiu a corporização dum conjunto de práticas que era pensado em Lisboa e implementado e desenvolvido pelos súbditos da Coroa portuguesa em todo o império, reino e colónias. Conhecer melhor estas actividades permite igualmente compreender de forma mais exacta a trajectória das peças existentes nas colecções museológicas e a forma como muitas destas colecções se originaram numa altura em que, em Portugal, a ciência se renovou como área de saber, em estreita ligação com a política, a economia, a sociedade.

\section{AS REFORMAS EDUCATIVAS UNIVERSITÁRIAS E A FORMAÇÃO DE UMA ELITE CIENTÍFICA E BUROCRÁTICA TRANSATLÂNTICA EM PORTUGAL SETECENTISTA}

Os actos de colectar e estudar as produções naturais e humanas dos mais variados cantos do mundo tiveram, entre outros aspectos, a utilidade de mostrar visual e fisicamente as diferenças, a estranheza, o exotismo das novas paragens que gradualmente se iam desvelando aos olhares dos europeus, especialmente daqueles que não estavam dispostos a arriscar a sua segurança e o conforto dos seus lares em viagens perigosas. Se o novo mundo era diferente, e se essa diferença podia ser constatada a partir da observação de especímenes naturais e de artefactos, então havia igualmente que estudá-los e tentar compreender o lugar que esses seres e objectos ocupavam nos sistemas cognitivos europeus. Esta curiosidade científica reflectia o interesse enciclopédico europeu - e ibérico - que tinha por ambição observar, compreender e classificar tudo o que acontecia à superfície dum globo que gradualmente ia desvelando os seus mistérios aos países europeus que controlavam e dominavam espaços em outros continentes.

Ora para os europeus da Modernidade, este saber do mundo físico, natural e humano, para além de permitir o exercício de poder, de soberania e o con- trolo político, destinava-se igualmente à exploração económica das riquezas dos novos mundos em benefício de uma humanidade que era obviamente a europeia. Os novos produtos originários de espaços extra-europeus, e a vontade de os explorar economicamente, encontram-se inevitavelmente indissociáveis de novas formas de colonialismo e de comércio transoceânico e de longa distância (Marples e Pickering, 2016, p. 1).

Depois de chegados à Europa, muitos especímenes exóticos integraram gabinetes de curiosidades, colecções científicas e jardins. Estes lugares simbolizavam a posição que a ciência adquirira na nova escala de valores e albergavam em si os saberes sobre o mundo: para estudo dos especialistas e para instrução dos príncipes das casas reais e das elites aristocráticas. Os objectos preciosos e as raridades eram organizados e sistematizados por forma a transmitir ordem teórica e material, e eram entendidos e interpretados de acordo com os sistemas científicos da Modernidade europeia. Paralelamente, criavam-se sistemas de informação eficazes que permitissem a sistematização dos dados que chegavam em quantidades cada vez maiores. Desta forma conferia-se sentido e coerência aos produtos que não eram familiares aos europeus.

Portugal não foi excepção a este esforço de recolecção e estudo científico, com a organização dos gabinetes de curiosidades a conhecer um desenvolvimento notável, particularmente a partir do reinado de D. João V. Ordenados de acordo com o espírito do coleccionismo barroco, estes espaços eram caracterizados, na definição de João Carlos Brigola, pela cultura de curiosidade e pela acumulação desordenada de objectos raros, excêntricos e excepcionais. Antiguidades, obras de arte, moedas e medalhas, espécimes naturais, fósseis e objectos maravilhosos acumulavam-se desordenadamente. Contudo, a maioria destes gabinetes, entre eles o do Paço Real da Ribeira, desapareceu com o terramoto de 1755 (Brigola, 2013, p. 8).

Os novos museus e gabinetes de história natural, os jardins botânicos e as colecções, ordenados de modo racional, coerente e sistemático, foram criados em Portugal a partir da segunda metade do século XVIII. Reflectiram fundamentalmente o gosto privado das elites pelo coleccionismo enciclopedista barroco. De entre estes, os mais notáveis seriam, na opinião do viajante e geógrafo veneziano Adrien $\mathrm{Balbi}^{1}$, os gabinetes do marquês de Angeja, do marquês de 
Abrantes, do cônsul-geral das cidades hanseáticas Adolfe Frédéric de Lindenberg, localizados em Lisboa; de José Bonifácio de Andrada e Silva, sediado em Coimbra e mais tarde transportado para o Brasil (Varela, 2014) ; e do visconde de Balsemão, situado no Porto (Balbi, 1822, II, p. 93).

No que diz respeito aos espaços museológicos estatais, embora Balbi fosse da opinião que nenhum museu, gabinete, observatório ou laboratório português pudesse ser equiparado às grandes instituições cientificas europeias, não deixava de reconhecer importância aos Gabinetes de História Natural e Jardins Botânicos da Ajuda e da Universidade de Coimbra, simultaneamente por serem projectos nacionais e devido à raridade dos materiais expostos (Balbi, 1822, II, pp. 92-94). De acordo com Brigola, em pleno período de reformas pombalinas e à luz da teoria política do Absolutismo Esclarecido, os museus de história natural e os jardins botânicos da Ajuda (1768) e de Coimbra (1772) adquiriram um novo significado. Na génese desta alteração estariam a educação filosófica dos príncipes e a reforma da universidade. Estes fenómenos explicariam o impacto cada vez maior das ciências físicas e naturais, a necessidade de observar directamente os seres e os objectos e a adopção do experimentalismo como metodologia educativa associada à fundação e ao equipamento de laboratórios e espaços museológicos (Brigola, 2013, p. 10).

Conquanto que o Gabinete de História Natural da Ajuda fosse inicialmente concebido com objectivos pedagógicos e recreativos direccionados para a educação dos infantes da Casa Real e se destinasse a apoiar o ensino prático de História Natural aos netos de D. José I, rapidamente se tornaria num centro de acolhimento e intercambio de espécimes. Transformou-se num pólo de estudo dos materiais provenientes de espaços europeus e extra-europeus; num local de experiências relacionadas com a aclimatação de espécies e aperfeiçoamento de culturas de plantas com interesse económico (Figueirôa e Silva, 2004, p. 717; Felismino, 2014, p. ii). Para além do museu de história natural, o complexo da Ajuda era ainda constituído por um jardim botânico, um laboratório de química e uma nova biblioteca dedicada à história natural. Conjuntamente era uma escola de desenho e gravura técnica, onde se estudavam e reproduziam os registos iconográficos de espécies zoológicas e botânicas e as representações cartográficas e geográficas que começavam a chegar em quantidade a Lisboa.
Provinham sobretudo do Brasil, devido ao recrudescimento do interesse científico e económico pelo mundo natural brasileiro e por razões políticas ligadas à definição das fronteiras coloniais entre os países ibéricos na América do Sul (Faria, 2001; Felismino e Lourenço, 2017, p. 17; AAVV, 1999).

Quanto ao segundo gabinete e jardim botânico, o seu estabelecimento justificava-se amplamente na medida em que a reforma da Universidade de Coimbra, fortemente influenciada pelo Espírito das Luzes, descentrava a aprendizagem do saber teórico e livresco para enfatizar uma instrução com base na observação directa dos seres, dos objectos e na experiência. Estes objectivos estão em articulação com a diminuição do papel até então conferido à lógica, à metafísica e à ética. Ao mesmo tempo, concediam uma relevância maior a disciplinas como a filosofia natural, a química e a física experimental. Confirmavam também a utilidade do conhecimento geográfico e científico-natural dos territórios nacional e ultramarino, nomeadamente através da realização de viagens científicas e do estudo dos espécimes que eram enviados pelos cientistas (Cruz e Pereira, 2016).

Deve-se sublinhar que, depois de 1772, a Universidade de Coimbra desenvolveu-se em estreita relação com o império pluricontinental português. Nomeadamente quando se tratava de formar agentes que actuavam nas missões geopolíticas e científicas realizadas nos espaços ultramarinos e, entre elas, as viagens filosóficas a Angola, Brasil, Cabo Verde e Moçambique. Ou quando se criavam novas infra-estruturas que estavam em sintonia e actuação coordenada com estas missões. Era nos jardins botânicos, nos gabinetes, em hospitais e fábricas ligadas a sectores estratégicos, como a cordoaria, que se recebiam e testavam novos produtos, se registavam as aplicações tradicionais dadas pelas populações locais a estes géneros e se experimentavam utilizações inovadoras.

Mas importa observar também que Coimbra foi, ao contrário do que se passou noutros reinos europeus, o único centro universitário existente no Império Português ${ }^{2}$. Esta situação singular foi determinante na homogeneização científica e ideológica das elites dominantes que ocupavam os mais variados postos no aparelho político, diplomático, institucional e administrativo do Estado, dentro e fora das fronteiras nacionais. A burocracia transatlântica formada em Coimbra estava destinada pela Coroa a participar activamente na renovação e na modernização admi- 
nistrativas que ocorreram nos espaços imperiais portugueses durante a segunda metade de setecentos, em reformas que requeriam indivíduos com conhecimentos médicos, botânicos, sanitários, mineralógicos, filosófico-naturais.

Clarifique-se igualmente que as reformas educacionais no ensino superior não pretendiam alterar intrinsecamente o status quo governativo ou o sistema político da monarquia pluricontinental lusa (Campos, 2018, pp. 124-7). O aperfeiçoamento do aparelho burocrático-administrativo radicava numa lógica racional, moderna e pragmática, tal como era ministrada na universidade reformada, no Real Colégio dos Nobres (1761) e nas academias militares restauradas pelo conde de Schaumburg-Lippe (1762-67). Através da actuação dum corpo burocrático-administrativo que se queria altamente competente e eficaz, a informação corporizava-se em projectos cartográficos baseados em medições astronómicas precisas, realizadas in loco; em levantamentos estatísticos demográficos, militares, comerciais e agrícolas exactos; numa taxonomia científica rigorosa e organizada do mundo natural; na concepção de novos métodos de desenvolvimento económico que valorizavam a agricultura.

Deve-se levar em consideração que esta cultura política de índole reformista ocorreu em Portugal numa altura em que os recursos auríferos provenientes das minas do Brasil tinham entrado em decadência (Figueiroa e Silva, 2004, p. 715). Adoptavam-se novos métodos que davam prioridade ao desenvolvimento agrário e a uma economia baseada na interacção e na interdependência entre os vários espaços imperiais (Paquette, 2013, p. 20). As reformas postas em marcha nestes finais de setecentos destinavam-se sobretudo a diminuir a dependência nacional das exportações e a valorizar produtos subaproveitados ou até então desconhecidos, originários do reino e das colónias (Cardoso, 2003, p. 6). Este clima de descobrimento ligado à natureza abria, portanto, oportunidades sem fim às ciências. A sociedade confiava fervorosamente no conhecimento científico com interesse prático e em soluções tecnológicas para reverter o declínio geopolítico do país e fazer com que ascendesse, de novo, ao estatuto de potência europeia, recuperando do atraso estrutural que tinha conhecido nos centénios anteriores. Estas eram concepções defendidas pela Coroa portuguesa, em nome do progresso, do bem-estar e da felicidade dos povos, considerados como ideais modeladores da actuação de monarcas e ministros ilustrados e cometidos à responsabilidade do Estado (Domingues, 2012).

Se a reforma pombalina do ensino superior tinha consolidado o lugar excepcional da Universidade de Coimbra na sociedade portuguesa, é preciso considerar igualmente que, a partir de 1779 , surge um outro locus de investigação e discussão científica. A Real Academia de Ciências de Lisboa aparece como um espaço de sociabilidade científico-cultural onde circulavam as elites que tinham frequentado as mais prestigiadas instituições de ensino, que liam os autores modernos e detinham um mesmo tipo de referências teóricas e metodológicas (Fonseca, 2017, p. 40). O carácter oficioso dos Estatutos desta Academia permitia-Ihe uma autonomia política que possibilitava a livre discussão de assuntos com interesse nacional nas suas sessões. Mas o prestígio da instituição e dos seus membros - entre eles contava-se D. João Carlos de Bragança e Ligne de Sousa Tavares Mascarenhas da Silva, 20 duque de Lafões e primo da rainha -, abria caminho junto dos círculos mais altos do poder, cujas decisões eram aconselhadas e influenciadas pelas correntes políticas e económicas debatidas nas sessões da Academia (Serrão, 1994, pp. XV-XVI; Silva, 2015, pp. 26-7).

Para além da incumbência genérica de recolher, analisar e difundir conhecimentos relacionados com as produções coloniais portuguesas e de incentivar a adopção de práticas agrícolas mais racionais e produtivas, a Academia tinha ainda como objectivo criar um gabinete de colecções. Neste caso, um Museu Nacional com vista ao "bem publico [e] a grande utilidade, que de huma similhante collecção, sendo bem ordenada, pode resultar para o adiantamento das Artes, Commercio, Manufacturas e todos os mais ramos da Economia". O lugar de destaque seria ocupado pelas produções naturais e humanas dos espaços coloniais (Anonimo, 1782, p. 3).

Em suma, dir-se-ia que os espaços da Ajuda e de Coimbra, em articulação com a Real Academia das Ciências, reflectiam o esforço da Coroa portuguesa para actualizar Portugal a nível científico e tecnológico e para exibir as suas colecções, numa altura em que a ciência dependia dos interesses políticos da monarquia. Ou seja, estes espaços significavam muito mais do que meros lugares de contemplação e ordenamento, de deleite e prazer (Cardoso, 2003, p. 9). Eram peças centrais na estratégia do desenvolvimento do Estado moderno e instrumentos essenciais "do progresso e do bem-estar do povo". Eram amplos 
espaços de estudo, debate e disseminação de ideias, métodos e técnicas modernos (Felismino e Lourenço, 2017, pp. 15-17; Carneiro, Simões e Diogo, 2000)³.

A par destes organismos oficiais, os historiadores têm dado cada vez mais relevância à influência exercida por um público ilustrado e interessado, diversificado e activo, constituído por intelectuais e homens esclarecidos, por comerciantes e homens de negócio ligados ao comércio transoceânico e à comercialização de produtos tropicais, por profissionais que eram avaliados em função do seu saber do mundo (boticários, editores, livreiros, etc.). Estes indivíduos compravam livros, mapas, jornais, enciclopédias; visitavam gabinetes e exposições; liam e ouviam ler e relatar em espaços públicos; procuravam estar actualizados em relação às matérias-primas que chegavam de outros lugares e às constantes inovações científicas e tecnológicas. Cruzavam-se nas ruas e nos espaços públicos de grandes cidades cosmopolitas, como era o caso de Lisboa, com o seu porto e espaços de socialidade existentes ao redor das infra-estruturas portuárias; nos terreiros e praças, nas ruas, nos cafés, nas estalagens, nas lojas e armazéns. Tal como nos gabinetes de curiosidades, nos salões e nos jardins particulares, nas bibliotecas e livrarias, nas academias.

Era nestes espaços que novas e exóticas maravilhas eram exibidas sob a forma de animais, sementes, plantas, artefactos, seres humanos; e que eram contadas e explicadas pelas vozes de marinheiros, soldados, mercadores, aventureiros. A curiosidade e o encantamento pelo mundo explicam o lugar central que a história natural ocupou na organização do universo mental do Século das Luzes. Tal como permitem compreender a participação activa destas populações urbanas no processo de formação e partilha do conhecimento sobre as bases naturais do mundo. Esta questão pode estar, sem dúvida, relacionada com o gosto pelo exotismo, com o que é moda, com hábitos sociais ligados a símbolos de distinção e prestígio social e cultural. Pode ainda ajudar a compreender o enorme sucesso editorial de romances que têm como pano de fundo as exóticas paragens das Caraíbas, do Índico ou do Pacífico, como é o caso de Paul et Virginie de Jacques-Henri Bernardin de Saint-Pierre (1788), As viagens de Gulliver de Jonathan Swift (1726) e Robinson Crusoe de Daniel Dafoe (1719).

Neste processo de formação e sensibilização da opinião pública, a imprensa teve, então, um papel decisivo na intensificação da circulação de saberes, onde "a produção do livro e da gravura acerca das ciências naturais - sem dúvida com o propósito instrumental e prático de desenvolvimento económico das colónias - não pode ser dissociada de um gosto haurido e difundido pelas elites, e concretizado no coleccionismo, na criação de jardins botânicos e na constituição de gabinetes ou museus" (Curto, 1999, p. 48). De entre as casas editoriais mais relevantes deste período, está, sem dúvida, a Tipografia Calcográfica e Literária do Arco do Cego, um projecto fomentado directamente pela Coroa e detentor do alto patrocínio do secretário de Estado da Marinha e Negócios Ultramarinos D. Rodrigo de Sousa Coutinho. A Casa do Arco do Cego esteve activa entre 1799 e 1801 e é considerada por muitos autores como um empreendimento editorial coerente, caracterizado pela divulgação de conhecimentos práticos e úteis e por uma actividade relevante na divulgação dos ideários iluministas das ciências aplicadas. Teve igualmente um papel pedagógico junto da população, ensinando-a na execução mais moderna, e rentável de muitas actividades. Dirigida por frei José Mariano da Conceição Veloso (Kury, 2015; Nunes e Brigola, 1999, pp. 51-75), a Casa do Arco do Cego foi responsável pela publicação de descrições, compêndios, ensaios, colecções, tratados, cartas, manuais, muitos deles traduzidos e ilustrados. Incidiam sobre temas que iam da economia agrícola à história natural, da engenharia à química, das belas artes às obras náuticas (Harden, 2016, pp. 116-129).

Numa altura em que a ciência era antes de mais uma ciência útil, é inevitável reconhecer que estes lugares de saber e de experimentação, tanto oficiais como informais, desempenhavam um papel político e económico relevante. Eram decisivos na implementação de políticas públicas a médio e longo prazo, até porque o conhecimento científico e tecnológico suportava e validava a actuação governamental. Legitimavam os projectos reformadores que tinham por objectivo diminuir ou superar o deficit da balança de comércio e maximizar a auto-suficiência económica nacional (Cardoso, 2003: 7). Simbolizavam ainda espaços de legitimação e afirmação de statu quo para os homens de letras e ciências provenientes dos espaços imperiais, que viam nas casas editoriais da Universidade, da Academia de Ciências ou no Arco do Cego oportunidades apreciáveis para publicar os seus escritos e obter reconhecimento público. 


\section{AS VIAGENS FILOSÓFICAS E A CONSTITUIÇÃO DE COLECÇÕES: REPRESENTAR VISUALMENTE OS ESPAÇOS IMPERIAIS PARA ESTUDO DOS ESPECIALISTAS E INSTRUÇÃO DOS PRÍNCIPES}

Vimos já como os espaços museológicos de Coimbra e da Ajuda se destinavam a contribuir activamente para a modernização de Portugal, um programa político-científico que teve o seu início no reinado de D. José I, sobretudo a partir do impulso dado pelo secretário de Estado do Reino Sebastião José de Carvalho e Melo, conde de Oeiras e marquês de Pombal, e que obteve continuidade nas reformas empreendidas no reinado de D. Maria I, com os secretários de Estado da Marinha e Negócios Ultramarinos Martinho de Melo e Castro (1716-1795) e D. Rodrigo de Sousa Coutinho (1755-1812).

Estes dois ministros eram defensores de uma cultura política que concebia os domínios portugueses na Europa, Ásia, África e América como uma unidade e "um sistema político" do qual o reino era o centro e entreposto para o comércio com a Europa. Reconheciam igualmente a pertinência de se averiguarem as potencialidades das colónias e de se estimular a complementaridade económica entre os espaços coIoniais e o reino (Curto, 1999, p. 26). Martinho de Melo e Castro vinha, pelo menos desde 1778, a coordenar politicamente um levantamento científico com pretensões enciclopedistas que tinha por objectivo produzir um conhecimento minucioso dos espaços imperiais através do levantamento, recolha, descrição e estudo das produções naturais e das "características físicas e morais" dos indígenas. Mas foi sobretudo com D. Rodrigo de Sousa Coutinho que "Ces reformes axées sur la modernisation du pays, ouvrirent le pays aux nouveautés scientifiques et techniques les plus récentes et en vogue, transformant le cabinet d'Ajuda en un espace stratégique de réception et d'échange de ces nouvelles créations et innovations» (Felismino e Lourenço, 2017, p. 19).

No interesse redobrado que estes secretários de Estado concediam à natureza e aos projectos reformistas agrários aliados ao conhecimento científico, os agentes da Coroa - com particular destaque para os governadores e capitães-generais das capitanias coloniais, como são os casos de Luís de Almeida Portugal Soares de Alarcão d' Eça e Melo Silva Mascarenhas, $2 \circ$ marquês de Lavradio, e de Luís de Vasconcelos e Sousa, 40 conde de Figueiró, no Rio de Janeiro; de Luís Pinto de Sousa Coutinho, 1o visconde de Balse- mão, e de Luís de Albuquerque de Mello Pereira Cáceres em Mato Grosso; e de D. Francisco Inocêncio de Sousa Coutinho em Angola -, tiveram um papel cada vez mais interveniente nos espaços periféricos do império com vista à recolha das produções requeridas pela Secretaria de Estado da Marinha e Negócios Ultramarinos e pelo Real Gabinete e Jardim Botânico da Ajuda (Pataca, 2015, pp. 42-3; Cruz, 2004, pp. 12325; Reis, 2014, p. 47; Carvalho, 2013, pp. 166-175; Domingues, 2001, pp. 823-38).

Não obstante a notável intervenção dos agentes imperiais em relação à história natural, o grande esforço de averiguação e sistematização das produções coloniais foi coordenado cientificamente por Domingos Vandelli, professor de História Natural na Universidade de Coimbra e director do Jardim Botânico da $A_{j u d a}{ }^{4}$. Destinava-se à elaboração de um ambicioso plano científico e político-económico em torno duma história natural das colónias que mobilizou vários segmentos sociais sob este objectivo comum. O projecto dependia do encaminhamento do conhecimento científico dos espaços periféricos extra-europeus em direcção ao centro imperial, graças à mediação de naturalistas, desenhadores, cartógrafos, governadores, bispos e homens do clero, soldados, médicos e cirurgiões, boticários, engenheiros-cartógrafos, preparadores, comerciantes, párocos, indígenas, etc. (Faria, 2001, p. 24; Pataca, 2016, p 85; Ferreira, 2016, p. 117; Conceição, 2016, p. 151).

É no enquadramento institucional e científico até agora mencionado que decorrem as viagens filosóficas, idealizadas por Vandelli em 1778. Nesta altura inicia-se a preparação da elite científica formada na Universidade de Coimbra em Filosofia Natural - e, consequentemente, sob a coordenação científica de Vandelli -, para realizar as grandes expedições às colónias (Ferreira, 2017). A preparação deste processo implicou a execução de pequenas viagens no reino e a ampliação da formação teórica e prática dos naturalistas escolhidos, feita sob a supervisão do jardineiro-chefe Júlio Matiazzi, no espaço museológico da Ajuda (Figueirôa e Silva, 2004, p. 717).

As viagens filosóficas são consideradas pela historiografia contemporânea como um instrumento de modernização utilizado pela Coroa numa altura em que a ciência e a técnica eram vistas como ferramentas imprescindíveis ao desenvolvimento do Estado Moderno. Tinham claras pretensões enciclopedistas em relação à natureza: visavam o inventário minucioso e exaustivo das espécies naturais e das produções 
humanas dos territórios sob domínio português. Deram origem a colecções de musgos, fósseis, aves, peixes, mamíferos, rochas, plantas, artefactos ligados às comunidades indígenas; a xilotecas e herbários, entre outros.

Não obstante a importância que foi dada à recolecção, estudo e classificação dos produtos naturais e humanos, os viajantes-naturalistas também se ocupavam dos assuntos que, nesta altura, eram particularmente marcantes para os espaços coloniais visitados, como era o caso dos conflitos geo-diplomáticos em regiões de fronteira colonial, da medição exacta das coordenadas terrestres do território e da sua representação cartográfica; das descrição das comunidades indígenas, suas características, produções e saberes; dos núcleos urbanos coloniais, géneros cultivados, doenças, causas da mortalidade; da identificação dos recursos naturais e de novos produtos com interesse para o mercado europeu; da localização das áreas de extracção de minerais e cultivo de produtos economicamente significativos. A par destes aspectos, buscavam ainda encontrar as leis e as lógicas divinas na criação da natureza, analisar as relações causais entre os seres, investigar funções corporais, desenvolver leis matemáticas, debater a origem da vida (Campos, 2018, p. 102; Raminelli, 2008, p. 101).

Muitas das observações corroboravam na consolidação das reformas científicas e económicas iniciadas no tempo do marquês de Pombal, particularmente no que dizia respeito à consolidação dos vínculos de dependência criados entre as economias colonial e metropolitana. Destinavam-se igualmente a permitir um apertado controlo político e uma eficiente exploração económica dos territórios coloniais portugueses. Tendo o propósito de elaborar o inventário do mundo natural e de dar conta da presença humana - tanto a colonizadora, como a indígena -, destinavamse a tornar "the empire less abstract" e a aumentar a interdependência entre as várias províncias ultramarinas e o reino (Paquette, 2013: 37). A par da relevância científica que detinham, constituíram-se, igualmente, como instrumentos de governo à distância (Raminelli, 2008; Felismino, 2014, p. ii).

As primeiras quatro grandes viagens filosóficas foram organizadas e financiadas pela Coroa em 1783. Destinaram-se aos espaços que, na segunda metade de setecentos, eram ainda desconhecidos e marginais, como era o caso da Amazónia, Angola, Moçambique e Cabo Verde. Contextualizaram-se na já referida lógica integracionista político-económica da época, segundo a qual cada uma das partes devia contribuir, de forma planeada e harmoniosa, para a grandiosidade e auto-suficiência do "todo" imperial, agora concebido como uma entidade política única constituída pelo reino e pelas partes formadas pelo Brasil, Angola, Guiné, Moçambique, Goa, Macau e os arquipélagos atlânticos. Este princípio basilar não significava necessariamente uma relação de igualdade entre os vários espaços, até porque o reino, ou seja, o centro imperial, era o principal beneficiário das políticas coloniais (Paquette, 2013, pp. 19-20).

De entre estas viagens filosóficas quero destacar, porque é a maior e a mais relevante, e ainda porque é a mais estudada pela historiografia, a expedição que levaria, entre 1783 e 1792, o naturalista Alexandre Rodrigues Ferreira com o jardineiro botânico Agostinho Joaquim do Cabo e dois desenhadores, Joaquim José Codina e José Joaquim Freire, aos sertões das capitanias do Pará, S. José do Rio Negro, Mato Grosso e Cuiabá . Ferreira e a sua equipa - que seria ampliada no terreno pela incorporação de dois oficiais índios especializados na conservação de espécies, Cipriano de Sousa e José da Silva, e por um número considerável de colaboradores informais que cooperariam com textos especializados, no envio de produtos naturais ou na transmissão de outros tipos informais de saberes -, recolheram exemplares da fauna, flora, mineralogia e etnologia amazónica e matogrossense, revelando um claro interesse enciclopédico pelas capitanias do Norte e Oeste da América Portuguesa.

Nesta avaliação concisa daquela que, para o caso português, é o paradigma da viagem filosófica, é preciso considerar que a expedição de Ferreira se sobrepôs, no tempo e num espaço significativo, às áreas abarcadas pelas demarcações de limites entre as coroas ibéricas na América do Sul na sequência da celebração dos Tratados de Madrid de 1750 e Preliminar de Santo Ildefonso de 1777. Isto é, numa altura em que redobrou a posse e o controlo deste vastíssimo espaço colonial que definia as fronteiras entre as coroas ibéricas na América do Sul (Domingues, 1991).

Concomitantemente, os principais rios do complexo hidrográfico amazónico foram fisicamente explorados e descritos em relatórios, diários, listagens de medições das coordenadas terrestres, mapas, feitos pelos cientistas - matemáticos-astrónomos e engenheiros-cartógrafos - que constituíam as terceira e quarta partidas de demarcação luso-brasileira, actuantes no terreno a partir de 1780. De alguma for- 
ma, pode afirmar-se que estes dois tipos de viagens, as de demarcação de limites e a filosófica, confluíram na construção de um saber que a Coroa queria que fosse o mais completo, preciso, detalhado e enciclopedista possível; e que fosse igualmente elucidativo sobre uma vasta área geográfica que, a partir de meados de setecentos, era alvo de uma intensa negociação conflitual política, diplomática e militar entre as coroas ibéricas. (Domingues, 1991; Figueirôa e Silva, 2004, p. 717; Faria, 2001, p. 38). Nesse sentido, as viagens são, tal como eram definidas por Alexandre Rodrigues Ferreira, simultaneamente filosóficas e políticas.

Inegavelmente, haverá que relacionar esta questão com o facto de ter sido esta viagem a melhor planeada pela Coroa Portuguesa (Simon, 1983). Ao contrário do que se passou com as outras missões realizadas em território africano - onde os naturalistas no decorrer das suas missões ocupavam cargos no aparelho administrativo local, nomeadamente como secretários do governo -, Ferreira pôde, ao longo de nove anos, dedicar-se exclusivamente às observações, às remessas, à redacção de memórias, diários, cartas, participações (Raminelli, 2008, p. 104). De igual modo, esta viagem obteve, mais que qualquer outra, recursos e apoios por parte dos poderes central e governamental regional. Mas, como foi observado por Ronald Raminelli, muitas das funções executadas por Ferreira ultrapassaram manifestamente as estritamente requeridas a um naturalista: "em poucas ocasiões, Alexandre Rodrigues Ferreira observou a natureza e as comunidades indígenas como um naturalista setecentista, mas antes como um leal funcionário da coroa lusitana (...) a viagem filosófica foi, sobretudo, um empreendimento de cunho colonial, destinado a mapear as potencialidades da natureza em favor do restabelecimento do comércio e agricultura das capitanias do norte" (Raminelli, 1998, pp. 7-8).

Nos relatórios, memórias, participações, diários, tratados, notícias e ofícios enviados pelo naturalista à Coroa, a Amazónia era avaliada como um campo propício à implantação de programas de desenvolvimento agrícola, baseados na exploração dos recursos naturais, no cultivo diversificado de novos produtos e na aclimatação de espécimes exógenas em relação às quais o reino tinha interesse económico (Lima, 1953). Ferreira menciona frequentemente as experiências que eram efectuadas com as drogas-do-sertão (o puxiri, cacau, cravo, gengibre, salsaparrilha, anil, arroz) ou com produtos exógenos que se queriam aclimatados (linho cânhamo, baunilha, canela). Não descurava igualmente as potencialidades minerais de Mato Grosso, onde procedeu à recolha de amostras raras de ouro. Tal como não deixou de apontar a originalidade das escassas manufacturas produzidas nos aldeamentos indígenas, como era o caso das cuias e das redes de tear, fabricadas pelas índias de Montalegre. Nos seus projectos para a expansão agrícola da Amazónia, o naturalista, inspirado no reformismo agrário defendido por Vandelli, apostava particularmente em propostas desenvolvimentistas agrícolas e extractivistas.

De igual modo, interessou-se por informações de natureza geográfica e estatística-demográfica sobre a presença colonial luso-brasileira. Estes temas estão presentes nas participações do Diário da Viagem Filosófica ao Rio Negro. As participações, juntamente com outras "memórias científicas" produzidas sobre a Amazónia setecentista, continuam a ser uma contribuição decisiva para o nosso entendimento do passado e do presente dum espaço que tanta relevância tem para o equilíbrio ambiental planetário e onde tantas espécies se encontram ameaçadas. A relevância destes textos é partilhada com os desenhos dos riscadores científicos e com as remessas de folhas, cascas, frutos, animais, madeiras, aves e outros produtos ligados ao registo das comunidades e dos conhecimentos tradicionais indígenas, de que as raras peças sobreviventes no MUHNAC, na Colecção Maynense da $\mathrm{ACL}$ e na Coleç̧ão de Antropologia do $\mathrm{MC}$ da UC são testemunhos marcantes (Safier, 2010, p. 134; Raminelli, 1998) $)^{6}$.

Como já sabemos, o projecto de Vandelli para o conhecimento científico das colónias não se esgotou na viagem de Alexandre Rodrigues Ferreira. Sucintamente, quero fazer uma referência às outras três viagens filosóficas que estão incluídas nesta primeira iniciativa da Coroa. Uma delas é a que o naturalista João da Silva Feijó realizou às ilhas de Cabo Verde entre 1783 e 1796. Juntando à missão científica o encargo de secretário do governo, Feijó envolveu-se em actividades de observação, análise, recolha, organização, conservação e envio de remessas científicas das ilhas de São Nicolau, Brava, Fogo, Santiago e Santo Antão (Roque e Torrão, 2013, I, pp. 21-22; Guedes, 1997, pp. 131-138). Enviou a Martinho de Melo e Castro relatórios sobre o clima, o solo, a vegetação e as produções agrícolas das ilhas e sobre a erupção do vulcão da ilha do Fogo de 1785, que presenciou. 
O mesmo naturalista, a acumular funções de sargento-mor, realizou ainda viagens pelo Ceará entre 1799 e 1816. Nesta capitania fez observações e escreveu memórias sobre as riquezas naturais encontradas, dando particular atenção a produtos como o salitre, as madeiras para a construção naval e as plantas com utilidade medicinal (Oliveira, 2013).

Uma outra expedição foi direccionada para Angola. Coordenada pelo naturalista Joaquim José da Silva (que tinha sido também nomeado para o cargo de secretário do governo desta colónia), era ainda constituída pelo desenhador italiano Ângelo Donati e pelo jardineiro José António. Ambos morreram pouco tempo após chegarem ao território. As investigações de Silva em Angola levaram-no a percorrer Benguela, Luanda, Cabinda, o rio Dande e Massangano. Recaíram especialmente sobre os recursos minerais em Cabinda e Massangano, mas também em relação a exemplares da fauna e flora locais. O naturalista produziu um número limitado de textos e enviou remessas de plantas, peixes, conchas, animais e um herbário ao complexo museológico da Ajuda (Raminelli, 2012, p. 49).

Finalmente, o baiano Manuel Galvão da Silva, acumulando funções de secretário do governo de Moçambique, dirigiu-se a Goa e à costa oriental de África. Coordenava uma equipe constituída pelo jardineiro João da Costa e pelo riscador António Gomes. Chegado à capital do Estado da Índia em 1784, realizou algumas observações de história natural. Ainda no mesmo ano seguiu para Moçambique, onde se viu envolvido em conflitos com funcionários coloniais. Ao longo de 10 anos e debatendo-se com inúmeros contratempos, conseguiu efectuar observações naturais, particularmente sobre minerais.

Se estas quatro viagens estruturam os planos de Domingos Vandelli para o conhecimento científico dos espaços ultramarinos, elas, no entanto, não esgotam o envolvimento dos agentes da Coroa e de particulares que, incutidos numa cultura científica, se empenharam em conhecer e dar a conhecer o mundo natural extra-europeu. Movidos por interesses próprios - a que, sem dúvida não serão alheios o reconhecimento dos serviços pessoais prestados à monarquia e as honras, mercês e recompensas inerentes a uma cultura politica própria de Antigo Regime -, actuando individualmente ou integrados em complexas redes transoceânicas de comércio e de informação, estes naturalistas, com formação académica ou autodidactas, envolviam-se na extraordinária e entu- siasmante actividade que, nestes finais de setecentos, era a recolha de plantas, insectos, aves, répteis, máscaras nativas e esqueletos humanos; bem como a elaboração de uma quantidade infinda de memórias, relações, métodos, catálogos, etc. que eram enviados para as dependências da Secretaria de Estado da Marinha e Negócios Ultramarinos e do complexo museológico da Ajuda. Contribuíram empenhadamente na inventariação dos produtos e na descrição do seu aproveitamento, revelando uma vontade colectiva de participar num exercício científico que tinha como objecto central o reconhecimento dos recursos naturais do Império, com especial incidência no Brasil.

Esta consciência social faz parte duma cultura científica que explica o recrudescimento de outras viagens filosóficas na América Portuguesa na mesma altura. De entre elas destacam-se, pela sua importância, as de frei José Mariano da Conceição Veloso, que, entre 1782 e 1790 e no cumprimento das directrizes do vice-rei Luís de Vasconcelos e Sousa, realizou à capitania do Rio de Janeiro, percorrendo trajectos que incluem a Serra do Mar em direcção a Santos, a llha Grande, Paraty e a serra de Paranapiacaba. Destas explorações destinadas à produção da Flora Fluminense, resultou o envio de enorme quantidade de espécimenes de flora e fauna para o Real Museu e Jardim Botânico da Ajuda (Kury, 2015; Pataca, 2016). Há igualmente a destacar as investigações mineralógicas feitas por Baltasar da Silva Lisboa à ilha das Cobras e à Serra dos Órgãos entre 1787 e 1797; as de José Álvares Maciel a Sabará, Caeté e arredores de Vila Rica em 1788-9; as de Simão Pires Sardinha a Minas Gerais; as viagens botânicas, agronómicas e mineralógicas de Joaquim de Amorim e Castro à Bahia entre 1787 e 1796 (Pataca, 2015).

Ermelinda Pataca, que tem vindo a estudar detaIhadamente as viagens científicas feitas à América Portuguesa durante a segunda metade de setecentos, considera que o entendimento das relações que se estabeleceram entre viajantes e políticos é determinante para se definir uma tipologia das viagens; e para se entenderem as redes clientelares articuladas entre secretários de Estado e coordenadores científicos como Vandelli, no reino, e os viajantes-naturalistas, na colónia.

Pondera igualmente que esta questão é decisiva no entendimento da evolução e das mudanças que ocorreram na ciência colonial e reinol durante o período em análise. Consequentemente, a historiadora entende que há "uma diferenciação muito acentuada entre 
as administrações dos ministros da Marinha e Negócios Ultramarinos" (Pataca, 2015, p. 50); ou seja, entre as opções políticas e geoestratégicas definidas por Martinho de Melo e Castro e por D. Rodrigo de Sousa Coutinho. Na sua opinião, durante a administração do primeiro secretário de Estado, entre 1777 e 1795, teria ocorrido um processo lento e cuidadoso de organização das primeiras viagens, marcado pela criação de instituições e pelo planeamento de modelos teóricos e paradigmáticos de actuação. Nota ainda que quando os naturalistas-viajantes regressavam ao reino, eram integrados nas instituições de ciência, de forma a conferir-lhes oportunidades não depreciáveis para estudarem os materiais colectados ao longo das viagens. Considera emblemático deste fenómeno a nomeação de Alexandre Rodrigues Ferreira para vice-director do Museu e Jardim Botânico da Ajuda, em 1793.

Já no período de D. Rodrigo de Sousa Coutinho (1796-1802), assistir-se-ia ao afastamento das figuras estruturantes que são Vandelli e Matiazzi e à ascensão de Félix de Avelar Brotero ${ }^{7}$ e frei José Mariano da Conceição Veloso. Nesta avaliação, Pataca considera que teria havido um enraizamento, uma permanência dos naturalistas em vários locais da colónia brasileira, o que teria como consequência a implantação das práticas científicas no terreno. Embora inspiradas no know-how adquirido nas viagens anteriores, estas expedições obteriam resultados "mais intensos", associados à actividade editorial da Casa do Arco do Cego. Exemplos desta fase seriam as viagens protagonizadas pelo naturalista pernambucano e médico formado na Universidade de Montpellier Manuel Arruda da Câmara aos sertões de Pernambuco, Piauí, Paraíba, Ceará, Maranhão e ao vale do rio São Francisco entre 1794 e 1799; as expedições botânicas e mineralógicas realizadas ao interior das Minas Gerais pelo naturalista e secretário do governo Joaquim Veloso de Miranda, na companhia dos desenhadores José Gervásio de Sousa Lobo e Apolinário de Sousa Caldas (Ferreira, 2016); e de João Manso Pereira, professor de gramática latina e naturalista, ao Rio de Janeiro, Minas e São Paulo (Pataca, 2015, pp. 50-53).

\section{MANUAIS E INSTRUÇÕES OU COMO PREPARAR OS NATURALISTAS PARA AS VIAGENS FILOSÓFICAS}

Já se referiu que muitos dos naturalistas, desenhadores e jardineiros botânicos escolhidos para integrar as expedições científicas ao serviço da Coroa eram luso-brasileiros formados na Universidade de Coimbra e que estavam ligados ao complexo museológico da Ajuda (Faria, 2001, p. 90). Teria sido para eles que Domingos Vandelli elaborou um manual de instruções no qual sublinhava a importância de se produzirem diários de viagem organizados, de se fazerem desenhos precisos e se conservarem correctamente os especímenes seleccionados.

A par deste manual, que se encontra datado de 1779 e se intitula Viagens filosóficas ou dissertação sobre as importantes regras que o filósofo naturalista nas suas peregrinações deve principalmente observar, existe outra compilação atribuída aos naturalistas do Real Museu da Ajuda. Com data de 1781, o Méthodo de Recolher, Preparar, Remeter, e Conservar os Productos Naturais. Segundo o plano que tem concebido, e publicado alguns Naturalistas, para o uso dos Curiosos que visitam os sertões, e costas do Mar destinavase a instruir os "menos capacitados" nos métodos de recolher, preparar, remeter e conservar os produtos que eram necessários a um museu de história natural. Ainda neste ano, a Real Academia de Ciências de Lisboa editava as Breves instrucções aos correspondentes da Academia das Sciencias de Lisboa sobre as remessas dos productos e notícias pertencentes à história da natureza para formar hum museo nacional, que apresentava, aliás, pontos comuns com o manual anterior no que dizia respeito aos métodos e técnicas de observação, colecta, preparação e remessa de produtos naturais (Anónimo, 1782; Pereira e Cruz, 2009; Pataca, 2015, p. 60) Dois anos depois - ou seja, no ano em que os naturalistas partiam para as colónias - José António de Sá publicava o Compêndio das observações que formam o plano da viagem política e filosófica que se deve fazer dentro da pátria.

Com todas as probabilidades, estes quatro manuais estariam disponíveis aos naturalistas-viajantes que, em 1783, iniciavam as viagens filosóficas a África, América e Ásia. Enquanto manuais de instruções, destinavam-se a assegurar uma uniformização e correcção dos procedimentos relacionados com a selecção, preservação e acondicionamento dos materiais destinados a longas viagens terrestres, fluviais e transoceânicas. Procuravam ainda assegurar-se de que os espécimenes chegados a Lisboa estavam completos e bem preservados, condição sine qua non para serem exibidos nos gabinetes de curiosidades e serem estudados. 
Assim sendo, estes manuais visavam "ordenar a experiência da viagem" e evitar que erros e omissões fossem feitos: estabeleciam normas precisas de actuação, definiam critérios de selecção e ordenação e fixavam métodos de observação, de recolha e de preservação dos espécimenes. Este complexo processo científico, que era iniciado nas partes mais afastadas do império, destinava-se a Lisboa, a Coimbra e às colecções nestes centros imperiais. Era nos gabinetes e museus do reino que estes materiais iriam ser expostos e representariam, simbólica e visualmente, os locais da América, África e Ásia onde a soberania portuguesa estava implantada (Schiavinatto e Pataca, 2016, p. 559).

Nesse sentido, a importância destes manuais, que visavam definir regras e métodos na observação científica e diminuir a probabilidade de omissão ou erro, era considerável. Os naturalistas em missão deviam idealmente remeter os exemplares prefeitos, as descrições exaustivas, as remessas acondicionadas de forma a chegarem ao ponto de destino inalteradas. Ser impreciso no trabalho de campo, produzir observações lacunares ou remeter espécimenes imperfeitos e mal preservados eram aspectos que inviabilizavam os resultados da viagem e podiam pôr em causa a credibilidade dos resultados por parte da República das Letras. Ou seja, de uma comunidade científica que produzia conhecimento num ambiente manifestamente transnacional e com a qual Domingos Vandelli falava, se correspondia e trocava espécimenes - e da qual faziam parte nomes tão sonantes como Casimiro Gómez Ortega, Carl von Linné, sir Joseph Banks, e instituições tão prestigiantes como o Real Jardim Botânico de Madrid, o Jardin du Roi de Paris, o Museu da Universidade de Uppsala, a Academia de Ciências e Artes da Rússia, em São Petersburgo, ou os Kew Gardens em Londres (Brigola, 2003, pp. 115138 e 273-7). Ou, tal como Cristiana Bastos sintetiza, que davam corpo às "networks that at that time brought together naturalists and things, projects, research interests, sites on earth, flows of knowledge" e que tornavam operativa a inserção das instituições de ciência portuguesas nas redes de conhecimento iluministas europeias (Bastos, 2013, pp. 13-14)

É preciso ter igualmente em consideração que, quando se tratava de viagens que eram executadas em espaços tão distantes como as franjas marginais da Amazónia, Mato Grosso, Angola ou Moçambique, as longas distâncias percorridas traduziam-se em largos meses e anos e em duríssimas condições físicas e psicológicas. Para além disso, temos vindo a referir ao longo deste artigo como as viagens organizadas durante o reinado de $D$. Maria I beneficiaram dum enquadramento de excepção que muito dificilmente se voltaria a repetir: a nível ideológico, político-institucional, científico, financeiro, diplomático. Consequentemente, a possibilidade de replicarem as observações e recolhas de espécimenes in loco seria altamente improvável. Assim, cumpriria aos manuais a função de diminuir as probabilidades de erro, esquecimento ou negligência por parte dos naturalistas.

Depois destas considerações introdutórias sobre os manuais de instruções, torna-se imprescindível referir que são muitos os historiadores que, sob a óptica da história da ciência e da história da arte, os têm analisado detalhadamente. De entre eles, destaco a análise feita por Ana Barbalho da Cruz e Magnus Pereira, que puseram a tónica na enunciação exaustiva dos manuais que foram escritos em Portugal e consideraram ainda os que foram produzidos noutros países europeus e chegaram ao conhecimento da elite científica de Coimbra e Lisboa, em língua vernácula ou traduzidos (Pereira e Cruz, 2012, pp. 115-133; Pereira e Cruz, 2009). Por sua vez, Ermelinda Pataca sintetizou as técnicas que deviam ser utilizadas para um maior sucesso na preparação, transporte e aclimatação das espécies (Pataca, 2016). Esta historiadora e lara Schiavinatto analisaram o papel específico destes manuais na harmonização da teoria e da prática, entre as técnicas e tecnologias utilizadas na produção, uso e circulação das imagens associadas às viagens e à produção científica (Schiavinatto e Pataca, 2016, pp. 559-564). Por seu turno, Silvia Figueirôa e Clarete P. Silva acentuaram a importância dos manuais como peças essenciais para a produção de conhecimento e enquanto expressão duma prática centralizadora de "fazer ciência" emanada a partir das instituições reinóis. Estas duas autoras deram um peso particular a estes compêndios, que consideram exemplos de "acompanhamento à distância", na medida em que forneciam normas e procuravam uniformizar métodos e procedimentos. Na sua análise, dão particular destaque às menções relacionadas com os produtos que os naturalistas deviam transportar na bagagem; à importância dos desenhos científicos, rigorosos e objectivos; aos processos correctos de recolha, selecção e preparação das espécies; ou à forma precisa como os registos deviam ser feitos (Figueirôa e Silva, 2004, pp. 718-19). 
Referi anteriormente que os naturalistas foram submetidos a uma preparação transversal e polivalente, destinada a conceder-Ihes uma preparação adequada a viagens direccionadas para regiões tão distantes, exóticas, tropicais. Para além de terem uma formação teórica que provinha das aulas da universidade e da leitura de manuais e livros científicos, era-lhes também ministrado um treino prático nos espaços museológicos e jardins botânicos da Ajuda ou de Coimbra. Aqui podiam estudar os especímenes anteriormente remetidos por funcionários coloniais e naturalistas-amadores (Cruz, 2004, p. 121). Mas os naturalistas em formação realizavam também viagens científicas de curta duração no reino, de que é exemplo a missão de cinco dias que Ferreira e os seus companheiros fizeram à mina de carvão do Cabo Mondego, em Buarcos, que parece ser uma clara componente prática na preparação dos naturalistas destinados a viagens futuras.

Quanto ao derradeiro teste para avaliar o seu grau de competência, terá sido talvez a autoria colectiva do Méthodo de Recolher, Preparar, Remeter, e Conservar os Productos Naturais..., que se apresenta como uma súmula de regras, procedimentos e técnicas, teóricos e práticos, que estes indivíduos deteriam às vésperas de partirem em viagem.

Uma das características destas elites científicas que cruzavam os vários espaços imperiais extra-europeus ao serviço da Coroa na segunda metade de setecentos era a de que detinham uma formação polivalente e revelavam curiosidade por várias áreas científicas. Alguns destes indivíduos tinham frequentado simultaneamente disciplinas distintas em mais que um curso na Universidade de Coimbra. Isso conferia-lhes habilitações para produzirem informação válida e credível tanto no que dizia respeito ao território e aos seus limites geográficos, como ao ambiente e aos produtos naturais. Podiam recolher, anotar e informar correctamente sobre as produções naturais com potencialidades económicas, tal como podiam descrever e representar com precisão os limites geográficos coloniais. Num período em que não havia uma concepção estanque de especialização ou de profissionalização - tal como hoje em dia as entendemos -, quem seguia a carreira da magistratura e da administração podia, com facilidade e eficiência, ocupar-se de observações científicas naturais; os naturalistas podiam interessar-se pelos cálculos astronómicos das coordenadas terrestres e representar o território cartograficamente; tal como muitos dos engenheiros-cartógra- fos e matemáticos-astrónomos estariam familiarizados com a descrição e recolha de produtos naturais (Domingues, 1991).

Não deixa de ser interessante mencionar como alguns autores se referiram a esta elite burocrática e científica transatlântica como sendo constituída por brasileiros. Acredito que o termo, tal como é utilizado neste contexto, será anacrónico ou pouco preciso e provavelmente justificado pela contextualização ideológica e política de viés nacionalista em que muitas das obras historiográficas a que me refiro foram produzidas. Em alternativa, creio que estes indivíduos, embora na sua maioria nascidos no Brasil, se autodefiniram como vassalos do soberano português; como membros plenamente integrantes deste vasto império constituído por múltiplas partes que deviam contribuir para o todo imperial - que é, como já mencionei, assimétrico.

Conforme tem sido apontado por István Jancsó e João Paulo Garrido Pimenta e mais recentemente por Lúcia Bastos Pereira das Neves, esta geração de letrados reconhecia que a sua pátria era a Bahia, São Paulo ou Minas Gerais; e que o seu país era o Brasil. Mas a nação à qual pertencia era a portuguesa e o monarca a quem devia lealdade era D. Maria I (Jancsó e Pimenta, 2000, pp. 389-440; Neves, 2018, p. 118). $E$, nesse sentido, estes homens são, por definição, luso-brasileiros nascidos no Brasil, formados na Universidade de Coimbra e nas Academias Militar e da Marinha e integram-se amplamente no statu quo. Isto é, constituíam as redes científicas, políticas, burocrática-administrativas que estavam ao serviço do Estado Português: "absorvidos na engrenagem maior de uma política de Estado, empenharam-se activamente os ilustrados brasileiros na construção do novo Império dos trópicos: a ilustração brasileira não pode ser, pois, identificada com "anticolonialismo" ou com a luta da colónia contra a metrópole” (Dias, 2005, p. 33).

Parece-me claro que fazem parte destas redes os bolseiros luso-brasileiros financiados pela Coroa portuguesa para realizar viagens de formação ao estrangeiro e para aprender nos países considerados mais desenvolvidos como executar melhor determinadas funções. De entre os elementos integrantes, podemos citar os nomes de José Bonifácio de Andrada e Silva e Manuel Ferreira da Câmara Bethencourt e Sá e associá-los à viagem mineralógica que fizeram a Espanha, França, Saxónia, Boémia, Hungria, Áustria, Prússia, Itália, Dinamarca, Suécia, Noruega como bolseiros do rei e ao serviço da Coroa portuguesa. Ou, então, 
Hipólito José da Costa Pereira Furtado de Mendonça e a missão científica que realizou aos Estados Unidos da América. Estes súbditos americanos eram académicos de pleno direito dos organismos científicos portugueses, com destaque para a Universidade de Coimbra e a Real Academia de Ciências de Lisboa (ex: Alexandre Rodrigues Ferreira, Joaquim Veloso de Miranda, Francisco José de Lacerda e Almeida, António Pires da Silva Pontes Leme, Simão Pires Sardinha, José Bonifácio de Andrada e Silva) (Silva, 2015, pp. 128, 325-6). As suas acções foram reconhecidas pelo Estado Português que os recompensou com mercês, rendas e nomeações para cargos relevantes nos órgãos administrativos e científicos (ex: Ferreira como vice-director do complexo museológico da Ajuda; Andrada e Silva como intendente-geral das Minas e Metais do Reino e membro do Tribunal de Minas; Ferreira da Câmara como intendente-geral das Minas e Metais de São Paulo; Pires da Silva Pontes como governador do Espírito Santo). Ou foram protegidos por destacados membros do governo, de que é exemplo Hipólito José da Costa Pereira Furtado de Mendonça, perseguido pela Inquisição e protegido por D. Rodrigo de Sousa Coutinho (Domingues, 2012, pp. 122- 23$)^{8}$

Estes homens circulavam pelos espaços imperiais espalhados por vários continentes, com destaque para África e América. E participaram, de forma notável, no fenómeno que Maria Odila Leite da Silva Dias designou acabadamente por "a interiorização da metrópole" - nomeadamente na vertente que incorporou geográfica e cientificamente os sertões americanos e africanos no espaço imperial português (Dias, 2005, pp. 7-37).

No panorama que aqui pretendo apresentar, tornase imprescindível referir que a escolha de Domingos Vandelli e do Estado Português para a execução das viagens filosóficas recaiu, de facto quase exclusivamente, sobre os vassalos que tinham nascido na América Portuguesa. Este padrão tem sido notado, mas, por enquanto, não está, na minha opinião, justificado de forma cabal. Procura-se explicar, por exemplo, pelo elevado número de presenças de luso-brasileiros nas cadeiras relacionadas com Filosofia Natural e com o interesse que teriam demonstrado por estas matérias que explicavam o novo mundo americano ${ }^{9}$. Contudo, sugiro que um factor a ser levado em conta nesta apreciação tenha a ver com o facto de estes indivíduos serem criollos, nascidos na colónia - tropical, exótica, com condições climatéricas especificas. Pro- vavelmente esperava-se que eles detivessem uma maior resistência às doenças tropicais e às febres que dizimavam os súbditos recém-chegados do reino. Esta inferência não me parece ilógica, sobretudo quando tenho em consideração que as preocupações dos naturalistas com o clima, as doenças tropicais, as febres, a mortalidade, a busca da cura (ligada, por exemplo, à exploração das propriedades curativas da quina e de produtos como a água-de-inglaterra), estiveram vincadamente presentes nas observações que produziram. Disso é referência clara as Enfermidades endémicas da capitania de Mato Grosso, da autoria de Alexandre Rodrigues Ferreira (Pôrto, 2008). Tal como estiveram presentes no dia-a-dia destes indivíduos que entravam pelos sertões e na morte de muitos deles, vitimados por febres e doenças tropicais, de que é exemplo Lacerda e Almeida nos sertões moçambicanos, o jardineiro Agostinho Joaquim do Cabo no Mato Grosso, o desenhador Ângelo Donati e o jardineiro José António nos sertões angolanos; um dos assistentes de Galvão em Moçambique.

\section{RECOLHER MATERIAIS E REGISTAR SABERES, ESCREVER TEXTOS E FAZER DESENHOS PARA ENVIAR AO REAL GABINETE DE HISTÓRIA NATURAL}

Uma perspectiva tradicional da história da ciência costuma olhar o saber científico que é produzido nos países ibéricos do século XVIII numa óptica dicotómica que associa às colónias a recolha e preparação dos especímenes e ao reino o estudo, classificação e catalogação dos materiais. No entanto, "The manner by which indigenous peoples of the Americas and elsewhere actually contributed to processes of collection, codification and dissemination of inquiries into the natural world has in turn become a core issue for those attempting to write more integrated and global histories of science" (Safier, 2010, p. 134). Ao reconhecer que nestes locais "periféricos" também se produzia conhecimento científico, embora de tipo diferente do gerado nos centros imperiais e nos espaços académicos (como eram a universidade, academias, hospitais, boticas), os historiadores reconhecem actualmente que as práticas locais e regionais coloniais foram estimulantes para a curiosidade científica portuguesa de setecentos.

Esta perspectiva leva cada vez mais em conta a interacção dos viajantes-naturalistas com as populações locais e a participação dos criollos e indígenas 
na definição e na resolução dos procedimentos empíricos e problemas técnicos relacionados com as viagens filosóficas aos espaços coloniais. Por exemplo, esta interacção espelha-se claramente nas redes ordenadas de correspondentes e colectores locais que colaboravam na recolha e no envio de espécies destinadas aos museus e jardins botânicos. Bem como na actuação conjunta de naturalistas, cartógrafos, astrónomos, médicos, físicos, comerciantes, indígenas, artesãos, mercadores, que, embora em níveis diferentes e em relação com as suas áreas específicas de interesse, eram actores participantes na organização da informação.

Para além disso, é inegável que os naturalistas e agentes da coroa em viagem pelos sertões dependiam intrinsecamente dos saberes de guias e informadores nativos, de intérpretes, remeiros e carregadores, que ajudavam os viajantes a progredir e a sobreviver no terreno (Safier, 2010, p. 134). O mesmo é aplicável em relação à recolha e preservação de materiais biológicos, à aquisição de artefactos junto das comunidades indígenas e ao registo de saberes tradicionais ameríndios, asiáticos ou africanos ligados à utilidade de espécies animais e vegetais, à preparação de alimentos, práticas de cura e conhecimentos fitoterápicos, aspectos em que se reconhece que a intervenção de intermediários é indispensável.

Na opinião de António Barrera Osorio, esta interacção que os naturalistas estabeleceram com as populações locais relaciona-se com interesses múltiplos e com procedimentos empíricos e colaborativos, por vezes situados longe dos centros imperiais e locais que estão tradicionalmente associados à produção científica, como é o caso de Lisboa ou Coimbra. Muitos destes procedimentos estão, por exemplo, ligados à recolha de dados e recolecção de espécies; à resolução de problemas técnicos; à conservação das espécies, seu acondicionamento e transporte; ou à obtenção de informações sobre as condições de vida e as produções económicas das populações locais. É num contexto colaborativo entre viajantes e populações locais que muita da informação produzida sobre os espaços coloniais está organizada e revela a sua riqueza. "Perhaps this is one of the most interesting aspects of this empirical culture: the emphasis on collaboration resulted from the need for experts from different fields to produce knowledge and solve problems related to the New World. One single area of expertise could not begin to cover the production of knowledge about the New World" (Barrera, 2010, p. 132).
Detentores de uma ambição enciclopédica em relação aos espaços americanos ou africanos em que se movimentavam, os viajantes-naturalistas produziram localmente informação que chegava ao Real Gabinete de História Natural da Ajuda, em Lisboa, sob a forma de textos, imagens, objectos, especímenes tridimensionais, plantas, sementes, peles, insectos e animais vivos que, depois de preparados e acondicionados, eram enviados em caixotes de madeira, caixas de folha-de-flandres, em barris, frasqueiras, gaiolas.

Não posso deixar ainda de observar que há uma complementaridade entre textos, desenhos, mapas, objectos tridimensionais e colecções. Esta informação estabelece entre si um diálogo que é indispensável para a identificação e a classificação das espécies, para a utilização ritual de máscaras e artefactos pelas comunidades indígenas, para a visualização do território percorrido, para a compreensão da expressividade física e demográfica de fortificações e núcleos urbanos, para a percepção da presença e da colonização portuguesas nos longínquos espaços imperiais. Ora neste sentido, as viagens filosóficas e os documentos que lhe estão associados constituem-se em instrumentos de governo à distância (Raminelli, 2012, p. 37).

Sabe-se que os naturalistas ligados às quatro primeiras viagens filosóficas procederam ao envio regular de produtos naturais para o Real Museu e Jardim Botânico da Ajuda. Remetidas com o objectivo de enriquecer as colecções da rainha D. Maria I, as remessas vinham acompanhadas por listas onde se elencavam exaustivamente os produtos. Depois de chegadas a Lisboa, estas produções alterariam a percepção que os portugueses tinham dos seus espaços imperiais extra-europeus, quando, a partir dos "centros de cálculo" que, nesta altura, eram Lisboa e Coimbra, estas produções naturais fossem integradas nos sistemas científicos e nas taxonomias em vigor (Kury, 2011, pp. 1-13).

“É a própria organização das colecções, dos gabinetes, dos jardins botânicos, dos museus de história natural, que confere ao conjunto dos objectos expostos e fruídos o carácter de sistema simbólico da organização que reproduz hierarquias e percursos com repercussão no plano social" (Cardoso, 2003, p. 15). Foi através de processos como este que a história natural emergiu como uma estrutura de conhecimento que produziu um ordenamento imperial das plantas e animais de acordo com a nomenclatura europeia. Neste sentido, pode-se dizer que o arquivo 
moderno do conhecimento ocidental foi construído sobre muitas das colecções e dos especímenes nativos estudados e reordenados a partir dos museus, dos gabinetes e dos jardins botânicos ibéricos (Smethrust, 2009, p. 7).

\section{AGRADECIMENTOS}

Trabajo realizado en el proyecto de investigación: "El coleccionismo científico y las representaciones museográficas de la Naturaleza y de la Humanidad", financiado por la Agencia Estatal de Investigación del Gobierno de España y el Fondo Europeo de Desarrollo regional (HAR2016-75331-P.AEI/FEDER, UE).

\section{NOTAS}

1. Nascido em Veneza, Adriano ou Adrien Balbi (1782-1848) foi autor de valiosos estudos geográficos, entre eles a obra Essai statistique sur le royaume de Portugal et d'Algarve (Paris, 1822), resultante duma demorada visita a Portugal. Neste livro faz uma descrição socioeconómica de Portugal no primeiro quartel do século XIX.

2. Comparativamente atente-se, por exemplo, no caso de Espanha que, logo em meados do século XVI, cria a Real y Pontifica Universidad de San Marcos em Lima, no Peru, (Real Provisión de 12 de Maio de 1551) e a Real y Pontificia Universidad de México (Real Cedula de 12 de Setembro). No ano seguinte, seria fundada por Real Cédula de 11 de Julho de 1552 a Real Universidad de La Plata, em Sucre, na Bolívia. É contudo de notar que esta universidade não chegou a instalar-se. De igual modo, a Real y Pontificia Universidad de Santo Tomás de Aquino, fundada em Santo Domingo por bula papal de 28 de Outubro de 1538 , só viria a ser reconhecida pela Coroa espanhola por Real Cédula de 23 de Fevereiro de 1558, tomando a denominação de Real y Pontificia Universidad de La Paz y de Gorjón.

3. Para estabelecer uma perspectiva comparada com o caso espanhol veja-se Lafuente, Puig-Samper et al. (1996).

4. Domenico Agostino Vandelli nasceu em 1735 em Pádua, cidade onde se doutorou em Filosofia. Foi convidado por Pombal para integrar o corpo docente do Colégio dos Nobres, em Lisboa, onde terá chegado em 1764. Em 1772 foi incorporado na Universidade de Coimbra onde foi nomeado como lente de Química e de História Natural. Dirigiu os trabalhos de fundação do Jardim Botânico da Ajuda e foi o primeiro director do Jardim. Participou activamente na fundação da Academia Real das Ciências de Lisboa e exerceu o cargo de director da classe das 'ciências da observação' Foi deportado para a ilha Terceira acusado de afrancesado devido à sua colaboração com os franceses por altura das Guerras Peninsulares (1807-1811). Regressou a Portugal em 1815 e morreu em Lisboa no ano seguinte. (http://cvc.instituto-camoes.pt/ciencia/p10.html) [consultado en 10/01/2019]

5. Nascido em Salvador em 1756, frequentou a Universidade de Coimbra onde se doutorou em 1778. Foi incumbido por Domingos Vandelli de chefiar a comissão científica destinada às capitanias do Pará, Rio Negro, Mato Grosso e Cuiabá. Regressado ao reino em 1793, Ferreira seria integrado como vice-director no Museu e Jardim Botânico da Ajuda. Em 1807, devido a graves problemas de saúde, deixou de trabalhar nas colecções que tinha colectado. Faleceu em Lisboa em 1815. (http://www.cedope.ufpr.br/ alexandre_ferreira.htm) [consultada en 10/01/2019]

6. Em 2010, no Ano Internacional da Biodiversidade, a Colecção de Alexandre Rodrigues Ferreira existente na Biblioteca Nacional do Brasil obteve o registo Memória do Mundo. Refira-se, ainda, o papel relevante que a Editorial Kapa teve, desde 2002, na disseminação sistemática, através da publicação de livros que fazem a reprodução fotográfica dos documentos sobreviventes da viagem filosófica à Amazónia; e dos catálogos das exposições realizadas por altura das comemorações do 20 centenário da viagem (Memória da Amazónia. Alexandre Rodrigues Ferreira e a viagem philosophica pelas capitanias do Grão-Pará, Rio Negro, Mato Grosso e Cuiabá, coord. M.L. Rodrigues de Areia, Maria Arminda Miranda e Tekla Hartman (Coimbra, 1991) e Brasil. Nas vésperas do mundo moderno, coord. Jill Dias (Lisboa, 1992). A este esforço de inventariação e disseminação da informação proveniente da viagem filosófica, deve ainda acrescentar-se o catálogo publicado por Rómulo de Carvalho, O material etnográfico do Museu Maynense da Academia de Ciências de Lisboa (Lisboa, 2000); e o catálogo de David Felismino (2014) sobre os materiais da viagem sobreviventes nas colecções da antiga Casa Real portuguesa. De entre os recursos electrónicos, o mais relevante é https://www.brasilianaiconografica.art.br/artigos/20106/colecao-alexandre-rodrigues-ferreira [consultado: $10 / 01 / 2019$ ]

7. Nascido em 1744, frequentou o curso de Direito Canónico da Universidade de Coimbra antes da reforma educativa pombalina. Interessando-se por ciência e ideais filosóficos, tornou-se pessoa de interesse do Santo Ofício da Inquisição. Em 1778 imigra para Paris, onde frequenta os espaços científicos (aulas, institutos, academias) da cidade ligados ao ensino da Filosofia Natural. Doutorou-se em Medicina na Universidade de Reims, mas não exerceu prática clínica, optando por dedicar-se exclusivamente ao estudo da Botânica. Voltou a Lisboa em 1790 e no ano seguinte foi nomeado lente da cadeira de Botânica e Agricultura da Universidade de Coimbra. Organizou a primeira escola prática botânica e organizou o jardim com uma classificação científica. Em 1811 foi nomeado director do Museu Real e Jardim Botânico da Ajuda e foi eleito deputado pela província da Estremadura às Cortes Constituintes de 1821. (http://www.arqnet.pt/dicionario/brotero.html) (consultado $10 / 01 / 2019$ ) 
8. http://www.cedope.ufpr.br/viagens_\&_expedicoes.htm (10/01/2019)

9. Pode, provavelmente, relacionar-se este interesse dos luso-brasileiros pela Filosofia Natural com o recrudescimento, no último terço do século XVIII, das "polémicas do novo mundo" e com as discussões em torno das teorias da inferioridade, imaturidade e degenerescência da natureza e da humanidade americanas, tal como tinham sido sustentadas por Cornelius de Paw (1739-1799) e George-Louis Leclerc, conde de Buffon (1707-1788). A reacção de muitos luso-brasileiros a esta polémica traduziu-se na criação das suas próprias teorias e identidades científicas regionais, de que são exemplo alguns escritos de José Bonifácio de Andrada e Silva, José da Silva Feijó e José Vieira Couto (Lopes e Varela, 2010; Silva, 2004, pp. 188-228)

\section{FONTES:}

Anónimo (1782), Breves instrucções aos correspondentes da Academia das Sciencias de Lisboa sobre as remessas dos productos e notícias pertencentes à história da natureza para formar hum museo nacional, Lisboa, Regia Officina Typografica

Balbi, Adrien (1822), Essai statistique sur le royaume de Portugal et d'Algarve, comparé aux autre états de l'Europe et suivi d'un coup d'oeil sur létat actuel des sciences, des lettres et des beaux-arts parmi les portugais des deux hémisphéres, Paris, Chez Rey et Gravier Libraires, vol. II.

\section{BIBLIOGRAFÍA}

AA. VV. (1999), Jardim Botânico da Ajuda, Lisboa, Jardim Botânico da Ajuda.

Areia, M.L. Rodrigues de; Miranda, Maria Arminda; Hartmann, Tekla (1991), Memória da Amazónia, Alexandre Rodrigues Ferreira e a viagem philosophica pelas capitanias de Grão-Pará, Rio Negro, Mato Grosso e Cuiabá (1783-1792), Universidade de Coimbra, Museu e Laboratório Antropológico.

Barrera Osório, António (2010), “Experts, nature and the making of Atlantic empiricism", Osiris, 25 (1), pp. 129-148.

Bastos, Cristiana (2013), "Of objects, networks, politics and poetry: the Royal Academy of Sciences in the context of the Enlightenment". En: Delicado, Ana (ed.), Associations and other groups in science: an historical and contemporary perspective, Cambridge, Cambridge Scholars Publishing, pp. 10-29

Brigola, João Carlos Pires (2003), Colecções, gabinetes e museus em Portugal no século XVIII, Lisboa, Fundação Calouste Gulbenkian e Fundação para a Ciência e Tecnologia.

Brigola, João (2013), "O privado que se faz público - os viajantes visitam museus e jardins botânicos (sécs. XVIII e XIX)". En: Congresso Anual da APH, 1-13 http://www.aph.pt/docs/ congressos/Comunicacao_do_Prof_Joao_Brigola_CongressoAPH2013.pdf (consultado a 10/01/2019)

Campos, Rafael Dias da Silva (2018), Os 15 de Montpellier: Medicina, política e relações de poder nas Luzes entre Montpellier, Coimbra e o Brasil (ca.1770 - ca.1820), Lisboa, Uni-
Ferreira, Alexandre Rodrigues (1972), "Observações gerais e particulares sobre a classe dos mamíferos observados nos territórios dos três rios, das Amazonas, Negro e da Madeira: com descrições circunstanciadas que quase todos eles deram os antigos e modernos naturalistas, e principalmente dos tapuios [1790]", Viagem Filosófica pelas capitanias do Grão-Pará, Rio Negro, Mato Grosso e Cuiabá. Memórias. Rio de Janeiro, Conselho Federal de Cultura.

Ferreira, Alexandre Rodrigues (s.d.), Viagem filosófica ao Rio Negro, s.l., Museu Paraense Emilio Goeldi, CNPq,

versidade Nova de Lisboa, FCSH, tese de doutoramento em História.

Cardoso, José Luís (2003), "A História Natural e a ciência económica na obra de Domingos Vandelli. Introdução". En: Memórias de História Natural. Domingos Vandelli, Porto, Porto Editora, pp. 1-15.

Carneiro, Ana, Simões, Ana, Diogo, Maria Paula (2000), "Enlightenment Science in Portugal: The Estrangeirados and Their Communication Networks", Social Studies of Science, vol. 30, no. 4, pp. 591-619 http://www.jstor.org/ stable/285782

Carvalho, Flávia Maria (2013), Os homens do rei em Angola: sobas, governadores e capitães mores, séc. XVII e XVIII, Niterói, Universidade Federal Fluminense, tese de Doutorado em História.

Carvalho, Rómulo de (2000), O material etnográfico do Museu Maynense da Academia de Ciências de Lisboa, Lisboa, Academia de Ciências de Lisboa.

Conceição, Gisele Cristina da (2016), “Natureza ilustrada: estudos sobre a filosofia natural no Brasil ao longo do século XVIII". En: Polónia, Amélia; Bracht, Fabiana; Conceição, Gisele C. e Palma, Monique (orgs.), História e ciência: ciência e poder na primeira idade global, Porto, Faculdade de Letras da Universidade do Porto, pp. 142-179.

Cruz, Ana Lúcia Barbalho da (2004), Verdades por mim vistas e observadas oxalá foram fábulas sonhadas: as viagens filosóficas como textos de auto-etnografia, Curitiba, Univer- 
sidade Federal do Paraná, tese de doutoramento em História.

Cruz, Ana Lúcia Barbalho da; Pereira, Magnus Roberto de Mello (2016), "Contra o notório sistema da ignorância artificial: a reforma pombalina da Universidade de Coimbra". En: Santos, António César de Almeida (org.), Ilustração, cultura escrita e práticas culturais e educativas, Ponta Grosso, Estúdio Texto, pp. 13-36.

Curto, Diogo Ramada (1999), "D. Rodrigo de Sousa Coutinho e a Casa Literária do Arco do Cego". En: AA. VV, A Casa Literária do Arco do Cego (1799-1801). Sem livros não há instrução. Lisboa: Biblioteca Nacional e Imprensa NacionalCasa da Moeda, pp. 15-49.

Dias, Jill (coord.) (1992) Brasil. Nas vésperas do mundo moderno, Lisboa, Comissão para a Comemoração dos Descobrimentos Portugueses.

Dias, Maria Odila Leite da Silva (2005), A interiorização da metrópole e outros estudos, 2a edição, São Paulo, Alameda.

Domingues, Ângela (1991), Viagens de exploração geográfica na Amazónia em finais do século XVIII: política, ciência e aventura, Funchal, Centro de Estudos de História do Atlântico.

Domingues, Ângela (2001), "Para um melhor conhecimento dos domínios coloniais: a constituição de redes de informação no Império português em finais do Setecentos". História, ciências, saúde - Manguinhos [online], vol.8, pp. 823-838. UmoutroOlhar. Diário da Expedição à Serra do Norte http:// www.scielo.br/scielo.php?script=sci_arttext\&pi$d=S 0104-59702001000500002$ (consultado a 10/01/2019)

Domingues, Ângela (2012), Monarcas, ministros e cientistas. Mecanismos de poder, governação e informação no Brasil Colonial, Lisboa, CHAM. https://run.unl.pt/handle/10362/15867 (consultado a 10/01/2019)

Faria, Miguel (2001), A imagem útil. José Joaquim Freire (17601847) desenhador topografo e de história natural, Lisboa, UAL.

Felismino, David (2014), Saberes, natureza e poder. Colecções científicas da antiga Casa Real Portuguesa, Lisboa, Museus da Universidade de Lisboa.

Felismino, David; Lourenço, Marta C. (2017), "Les cabinets de physique des rois du Portugal (XVIIle-XIXe siècles). Organisation, dispersion et collections perdues", Artefact. Techniques, histoire et sciences humaines, 5, pp. 11-26. [en línea], https://journals.openedition.org/artefact/599.

Ferreira, Breno Ferraz Leal (2016), Economia da natureza. A História Natural entre a Teologia Natural e a Economia Política (Portugal e Brasil, 1750-1822), Universidade de São Paulo, FFLCH: tese em História.

Ferreira, Gustavo Oliveira (2017), “A ciência como estratégia social: as actividades científicas de Domingos Vandelli nas redes clientelares de Portugal 1764-1788". En: Araújo, Ana Cristina e Fonseca, Fernando Taveira da (coords.), A universidade pombalina: ciência, território e colecções científicas, Coimbra, Imprensa da Universidade de Coimbra, pp. 139$190 \mathrm{http}: / /$ hdl.handle.net/10316.2/43174 (consultado a 10/01/2019
Figueirôa, Silvia F. de M.; Silva, Clarete Paranhos da (2004), "Aspectos mineralógicos das viagens filosóficas pelo território brasileiro na transição do século XVIII para o século XIX", História, ciência, saúde - Manguinhos, 10 (3), pp. 713-29.

Fonseca, Fernando Taveira da (2017), “Uma primeira educação do olhar: universidade e estudantes de Coimbra na transição reformista". Em Araújo, Ana Cristina e Fonseca, Fernando Taveira da (orgs.), A Universidade Pombalina: ciência, território e colecções científicas, Coimbra, Imprensa da Universidade de Coimbra, pp. 15-50. https://doi. org/10.14195/978-989-26-1366-6 (consultado a 10/01/2019)

Guedes, Maria Estela (1997), “João da Silva Feijó: viagem filosófica a Cabo Verde”, Asclepio, XLIX, 1, pp. 131-138.

Harden, Alexandra R. de Oliveira (2016), "Tradução, história e iluminismo luso-brasileiro: a Casa Tipográfica do Arco do Cego e as línguas do progresso", em Santos, António César de Almeida (org.), Ilustração, cultura escrita e práticas culturais e educativas, Ponta Grosso, Estúdio Texto, pp. 107-129.

Jancsó, István; Pimenta, João Paulo Garrido (2000), “Peças de um mosaico ou apontamentos para o estudo da emergência da identidade nacional brasileira", Revista de História das Ideias, 21, 389-440.

Kury, Lorelai (2011), “As viagens luso-americanas e as práticas científicas do Século das Luzes". En: Anais do XXVI Simpósio Nacional de História - ANPUH, São Paulo, pp. 1-13.

Kury, Lorelai (2015), “O naturalista Veloso", Revista de História, 172, pp. 243-277. (http://dx.doi.org/10.11606/issn.23169141.rh.2015.98752) (consultado a 10/01/2019)

Lafuente, Antonio; Puig-Samper, Miguel Angel, et al. (1996), "Literatura científica moderna". En: Aguilar Piñal, Francisco (ed.), Historia literaria de España en el siglo XVIII, Madrid: Ed. Trotta - CSIC, pp. 965-1028.

Lima, Américo Pires de (1953), O Doutor Alexandre Rodrigues Ferreira, Lisboa, Agência Geral das Colónias.

Lopes, Maria Margaret; Varela, Alex (2010), “Viagens, tremores e conchas: aspectos da natureza da América em escritos de José Bonifácio de Andrada e Silva, José Hipólito Unanué e Dámaso Antonio Larrañaga", Boletim do Museu Paraense Emilio Goeldi. Ciências Humanas, 5, n. 2, pp. 227-242.

Marples, A.; Pickering, V. R. M. (2016), “Exploring cultures of collecting in the early modern world", Archives of Natural History, 43 (1), pp. 1-20 [en línea], doi: 10.3366/ anh.2016.0342 (consultado a 10/01/2019)

Neves, Lúcia Maria Bastos Pereira das (2018), "Brasil e Portugal: Identidades distintas? (1820-1825)". En: Neves, Lúcia Maria Bastos Pereira das; Melo Ferreira, Fátima de Sá, e Pereira, Guilherme das Neves (orgs.), Linguagens da identidade e da diferença no mundo ibero-americano (1750-1890), Jundiaí, Paco Editorial, pp. 115-131.

Nunes, Maria de Fátima; Brigola, João Carlos (1999), “José Mariano da Conceição Veloso (1742-1811) - um frade no universo da natureza". En: AA. VV, A Casa Literária do Arco do Cego (1799-1801). Sem livros não há instrução. Lisboa: 
Biblioteca Nacional e Imprensa Nacional-Casa da Moeda, pp. 51-75.

Oliveira, António José Alves de (2013), “Viagens filosóficas e representações do mundo natural nos escritos de João da Silva Feijó - capitania do Ceará (1799-1816)". En: XXVII Simpósio Nacional de História, Natal, pp. 1-17. http://www. snh2013.anpuh.org/resources/anais/27/1364569120_ARQUIVO_viagensfilosoficaserepresentacoesdomundonatural. pdf (consultado a 10/01/2019)

Paquette, Gabriel (2013), Imperial Portugal in the Age of the Atlantic Revolutions. The Luzo-Brazilian world, c. 1770-1850. Cambridge, Cambridge University Press.

Pataca, Ermelinda Moutinho (2015), Mobilidades e permanências nos viajantes no mundo português. Entre práticas $e$ representações científicas e artísticas. São Paulo, Universidade de São Paulo, Faculdade de Educação, Tese de livre-docência.

Pataca, Ermelinda Moutinho (2016), "Coleta, transporte e aclimatação de plantas no Império Luso-Brasileiro", Museologia \& Interdisciplinaridade, 9 (5), pp. 84-104.

Pereira, Magnus Roberto de Mello e Cruz, Ana Lúcia Rocha Barbalho da (2009), "O viajante instruído: os manuais portugueses do lluminismo sobre os métodos de recolher, preparar, remeter e conservar produtos naturais". En: Doré, Andréa e Santos, António Cesar de Almeida (orgs.), Temas setecentistas. Governo e populações no Império português, Curitiba: UFPR/SCHLA, pp. 241-251.

Pereira, Magnus Roberto de Mello e Cruz; Ana Lúcia Rocha Barbalho da (2012), "Instructio Peregrinatoris: algumas questões referentes aos manuais portugueses sobre métodos de observação filosófica e preparação de produtos naturais da segunda metade do século XVIII". En: Kury, Lorelai, Gesteira, Heloisa (org.), Ensaios de História da Ciência no Brasil: das Luzes à nação independente, Rio de Janeiro, EdUERJ.

Pôrto, Ângela de Araújo (2008), Enfermidades endémicas da Capitania de Mato Grosso: a Memória de Alexandre Rodrigues Ferreira, Rio de Janeiro, Editora Fiocruz.

Raminelli, Ronald (1998), "Ciência e colonização. Viagem filosófica de Alexandre Rodrigues Ferreira", Revista Tempo, 6

Raminelli, Ronald (2008), Viagens ultramarinas. Monarcas, vassalos e governo à distância, São Paulo: Alameda.

Raminelli, Ronald (2012), "Ilustração e Império Colonial", História, 31 (2), pp. 36-68.
Reis, Alexander Lima (2014), "Ciência e técnica na produção do corante do anil e da cochonilha no Rio de Janeiro colonial (1772-1789)", Meridional, revista chilena de Estudios Latinoamericanos, 3, pp. 37-59.

Roque, Ana Cristina; Torrão, Maria Manuel (coords.) (2013), De Cabo Verde para Lisboa. Cartas e remessas cientificas da expedição naturalista de João da Silva Feijó (1783-1796), vol. I e II, Lisboa: IICT.

Safier, Neil, (2010) "Global knowledge on the move. Itineraries, Amerindian narratives and deep histories of science", Isis, 101, pp. 133-145.

Schiavinatto, lara Lis; Pataca, Ermelinda Moutinho (2016), "Entre imagens e textos: os manuais como práxis de saber", História, ciências, saúde - Manguinhos, 23 (2), pp. 551-566.

Serrão, José Vicente (1994), "Introdução", em Domingos Vandelli, Aritmética política, economia e finanças, Lisboa: Banco de Portugal, pp. 13-36.

Silva, Clarete Paranhos da (2004), Garimpando memórias: as ciências mineralógicas e geológicas no Brasil na transição do século XVIII para o XIX, Campinas, Universidade Estadual de Campinas, Instituto de Geociências, tese de doutorado em Ciências.

Silva, José Alberto Teixeira Rebelo da (2015), A Academia Real das Ciências de Lisboa (1779-1834): ciências e hibridismo numa periferia europeia. Lisboa, Universidade de Lisboa, Faculdade de Ciências.

Simon, William Joel (1983), Scientific expeditions in the Portuguese overseas territories (1783-1808) and the role of Lisbon in the intellectual-scientific community of the late eighteenth century. Lisboa, Instituto de Investigação Cientifica Tropical.

Smethrust, Paul (2009), "Introduction". En: Kuehn, Julia and Paul Smethrust, Paul (eds.), Travel writing, form and Empire. The poetics and politics of mobility, New York-London, Routledge, pp. 1-18.

Varela, Alex (2014), "Livros, leituras, impressos, bibliotecas e colecções na trajectória do naturalista José Bonifácio de Andrada e Silva (1780-1838)". En: Cruz Ferreira, Tânia Bessone da Cruz; Ribeiro, Gladys Sabina, e Gonçalves, Monique de Siqueira (orgs.), O Oitocentos entre livros, livreiros, missivas e bibliotecas, São Paulo, Alameda Casa Editorial, pp. 15-44.

\section{RECURSOS ELECTRÓNICOS: (Consultado a 10/01/2019)}

https://www.brasilianaiconografica.art.br/artigos/20106/ colecao-alexandre-rodrigues-ferreira

http://www.humanas.ufpr.br/portal/cedope/ 